American Journal of Infectious Diseases 5 (2): 135-141, 2009

ISSN 1553-6203

(C) 2009 Science Publications

\title{
The Flavonoid, Quercetin, Inhibits HIV-1 Infection in Normal Peripheral Blood Mononuclear Cells
}

\author{
${ }^{1}$ Madhavan P.N. Nair, ${ }^{1}$ Zainulabedin M. Saiyed, ${ }^{1}$ Nimisha H. Gandhi and ${ }^{2}$ C.N. Ramchand \\ ${ }^{1}$ Department of Immunology, College of Medicine, \\ Florida International University, Miami, FL 33199, USA \\ ${ }^{2}$ Laila Pharmaceuticals Pvt. Ltd., Arudra Street, TS Krishna Nagar, Mogappair, \\ Chennai-600 037, India
}

\begin{abstract}
Problem statement: Flavonoids and related polyphenols, have been known to possess cardioprotective, anti-tumor, anti-inflammatory, anti-allergic and anti-viral activities. Previous studies have shown that flavonoid, quercetin significantly downregulates expression of pro-inflammatory cytokines in cultured cells via modulation of NFKB and p38MAPK signaling pathways. In the current study, we hypothesize that quercetin exerts anti-HIV activity by differential modulation of pro-and anti-inflammatory cytokine expression in normal PBMCs. Approach: Cultures of PBMC received either different concentrations of quercetin $(1-50 \mu \mathrm{M})$ or media alone. The anti-HIV effects of quercetin was evaluated in an in vitro infection model by quantitaing the HIV-1 LTR gene suppression by quantitative Real Time PCR, HIV-1 p24 antigen production by ELISA and viral infectivity by MAGI cell assay. Results: Our results showed that quercetin significantly downregulates p24 antigen production, LTR gene expression and viral infectivity in a dose dependent manner $(5-50 \mu \mathrm{M})$ as compared to HIV infected untreated control PBMCs. Further, we reported that quercetin significantly downregulated the expression of the pro-inflammatory cytokine, TNF- $\alpha$ with concomitant upregulation of anti-inflammatory cytokine IL-13 as determined by measurement of gene expression and protein production. A higher level of IL-13 is known to inhibit TNF- $\alpha$ production and also HIV-1 infection. Thus, differential modulation of pro-and anti-inflammatory cytokines could be one of the possible mechanisms for the anti-HIV effects of quercetin. Conclusion: Better understanding of the mechanisms underlying the anti-HIV effects of quercetin may help to develop a new neutraceutical agent useful in the treatment of HIV-1 infected subjects in conjunction with conventional therapeutic regimens.
\end{abstract}

Key words: Quercetin, anti-HIV, inflammatory cytokines

\section{INTRODUCTION}

Discovery of effective and less toxic antiviral agents is a high priority in the search for more effective therapies against HIV. Flavonoids comprise a large class of low molecular weight polyphenolic compounds ubiquitously distributed in food plants. Flavonoids are enriched in certain vegetables, fruits, seeds and beverages (e.g., tea and wine) and are regarded as a class of semi essential nutrients for humans. Dietary intake of flavonoids is highly variable, with estimation ranging from $23^{[1]}$ to more than $500 \mathrm{mg}$ day $^{-1[2]}$. Flavonoids display a diverse array of biological effects including antioxidant, anti-inflammatory and anti-tumor activities with no apparent toxic side effects on cells ${ }^{[3-6]}$.
These beneficial effects of flavonoids have been attributed to their antioxidant and anti-inflammatory properties.

Quercetin, one of the polyphenolic flavonoids, is known to have effects on a variety of inflammatory processes and immune functions ${ }^{[7-14]}$. Tumor Necrosis Factor (TNF)- $\alpha$ is a major pro-inflammatory cytokine that regulates the growth, proliferation, differentiation and viability of activated leukocytes. Previous studies have shown that quercetin suppresses TNF- $\alpha$ induced IL-8 and MCP-1 expression in cultured human synovial cells ${ }^{[15]}$. Likewise, several studies have demonstrated the inhibitory effects of quercetin on the expression of inflammatory cytokines by cultured cells ${ }^{[16,17]}$. Recent study reported in HMC-1 human mast cell line has

Corresponding Author: Madhavan P.N. Nair, Department of Immunology, Florida International University, College of Medicine, HLS I 307/308/311, 11200, SW 8th Street, Miami, Florida 33199 Tel: 305-348-1490/1491/1492/1493 Fax: 305-348-1494 
indicated that quercetin effects on inflammatory cytokines are mediated through the modulation of NF$\kappa \mathrm{B}$ and p38 MAPK signaling pathways ${ }^{[18]}$. Previously, we have also demonstrated the inhibitory effects of quercetin on TNF- $\alpha$ production in normal Peripheral Blood Mononuclear Cells (PBMCs) and this effect is mediated by downregulation of NFKB and $\mathrm{I} \mathrm{B}^{[19]}$. Moreover, our laboratory has also shown that quercetin inhibits HIV-1 entry co-receptor CCR5 in normal PBMC in a dose dependant manner ${ }^{[20]}$.

Although, earlier reports showed the antiviral activity of quercetin, the pharmacological action of quercetin on inflammatory cytokines and the underlying mechanisms are not sufficiently investigated. Therefore, we hypothesize that quercetin exerts antiHIV activity by differential modulation of pro-and antiinflammatory cytokine expression in normal PBMCs. In the current study, we report the inhibition of HIV-1 replication and virus infectivity by quercetin in normal PBMC as evaluated by HIV-1 p24 antigen production, HIV-1 LTR gene suppression and MAGI cell assay and the mechanism may involve suppression of proinflammatory cytokine (TNF- $\alpha)$, with a reciprocal upregulation of anti-inflammatory cytokine, IL-13.

\section{MATERIALS AND METHODS}

Cell culture: Normal Peripheral Blood Mononuclear Cells (PBMC) were isolated by density gradient centrifugation process from HIV-1, HIV-2 and hepatitis $\mathrm{B}$ seronegative donor leukopacks as described earlier by us $^{[19]}$. PBMC $\left(3 \times 10^{6}\right.$ cells $\left.\mathrm{mL}^{-1}\right)$ were cultured in RPMI 1640 medium (Invitrogen, Grand Island, NY) containing $10 \%$ fetal bovine serum, penicillin $100 \mathrm{U} \mathrm{mL}^{-1}$, streptomycin $100 \mathrm{mg} \mathrm{mL}^{-1}$ and $2 \mathrm{mM} \mathrm{L-Glutamine}$ (Gibco-BRL, Gaithersburg, MD) at $37^{\circ} \mathrm{C}$ in $5 \% \mathrm{CO}_{2}$ incubator.

HIV-1 IIIB infection: HIV-1 IIIB, CXCR4-tropic, X4 virus strain (Cat \#398) was procured through $\mathrm{NIH}$ AIDS Research and Reference Reagent Program. PBMCs $\left(3 \times 10^{6}\right.$ cells $\left.\mathrm{mL}^{-1}\right)$ were infected with HIV-1 IIIB virus at a concentration of $10^{3.0} \mathrm{TCID}_{50} \mathrm{~mL}^{-1}$ cells for $3 \mathrm{~h}$ as described by the supplier. Cells were washed and cultured in the presence of quercetin (SigmaAldrich, St. Louis, MO) at concentrations ranging between $0-50 \mu \mathrm{M}$ for 7 days at $37^{\circ} \mathrm{C}$ in $5 \% \mathrm{CO}_{2}$ incubator. These concentrations selected for the in vitro studies are similar to levels found in plasma of human subjects that have ingested 150 or $300 \mathrm{mg}$ of quercetin $^{[21]}$. The culture supernatants were harvested and stored at $-70^{\circ} \mathrm{C}$ until further analysis for HIV-1 p24 antigen protein production by commercially available
ELISA kit as per manufacturer's instructions (Zeptometrix, Buffalo, NY) and cell pellets were used for RNA extraction and analyzed by qRT-PCR for LTR gene expression.

Quantitative Real Time PCR (qRT-PCR): RNA from cell pellets was extracted using RNAeasy mini kit (Qiagen, GmbH, Germany) followed by cDNA synthesis using high capacity reverse transcriptase cDNA kit (Applied Bio systems, Foster City, CA, USA) to perform qRT-PCR. Relative abundance of each mRNA species was assessed using SYBR green master mix from Stratagene using Mx3000P instrument which detects and plots the increase in florescence versus PCR cycle number to produce a continuous measure of PCR amplification. To provide precise quantification of initial target in each PCR reaction, the amplification plot is examined at a point during the early $\log$ phase of product accumulation. This is accomplished by assigning a fluorescence threshold above background and determining the time point at which each sample's amplification plot reaches threshold (defined as the threshold cycle number or $\mathrm{C}_{\mathrm{T}}$ ). Differences in threshold cycle number are used to identify the relative amount of PCR target contained within each tube ${ }^{[22]}$. Relative mRNA species expression was quantitated and expressed as transcript accumulation index $\left(\mathrm{TAI}=2^{-\Delta \Delta \mathrm{CT}}\right)$, calculated using the comparative $\mathrm{C}_{\mathrm{T}}$ method $^{[23]}$.

MAGI Assay to measure HIV-1 infectivity: To observe the effects of quercetin on HIV-1 infectivity in PBMC, we used the MAGI cell assay. This assay was intended to quantitatively measure virus infectivity ${ }^{[24]}$. The MAGI (multinuclear activation of a galactosidase indicator) cells are HeLa derived cells stably transfected with CD4 and a reporter construct consisting of the $\beta$-galactosidase gene (which is modified to localize to the nucleus) driven by a truncated HIV-1 LTR. Expression of the $\beta$-galactosidase gene is Tat-dependent such that an incoming virus must produce active Tat protein to drive expression of the reporter. MAGI cells $\left(4 \times 10^{4}\right.$ cells well $\left.{ }^{-1}\right)$ were plated in a 24 well plate and were treated in duplicate with $100 \mu \mathrm{L}$ cell suspension of PBMC's that were infected with HIV-1 IIIB virus and subsequently treated with quercetin $(5-50 \mu \mathrm{M})$. A total of $200 \mu \mathrm{L}$ of DMEM supplemented with $10 \% \mathrm{FCS}, 100 \mathrm{U} \mathrm{mL}^{-1}$ penicillin, $100 \mu \mathrm{g} \mathrm{mL}^{-1}$ streptomycin, $0.25 \mu \mathrm{g} \mathrm{mL}^{-1}$ fungizone and $300 \mu \mathrm{g} \mathrm{mL}^{-1}$ glutamine containing DEAE-Dextran at a concentration of $15 \mathrm{mg} \mathrm{mL}^{-1}$ was added to the MAGI cells and infected cells were incubated for 3 days at $37^{\circ} \mathrm{C}, 5 \% \mathrm{CO}_{2}$. Cells were fixed and stained with 5- 
bromo-4-chloro-3-indolyl-D-galactopyranoside (X-Gal) and blue cells were counted as infected cells.

Stimulated cytokine gene expression and protein secretion: PBMCs $\left(3 \times 10^{6}\right.$ cells $\left.\mathrm{mL}^{-1}\right)$ were stimulated with Phorbol Myristate Acetate (PMA) $\left(5 \mathrm{ng} \mathrm{mL}^{-1}\right)$ and $\mathrm{Ca}^{2+}$ ionophore $\left(50 \mathrm{ng} \mathrm{mL} \mathrm{mL}^{-1}\right)$ for $24-96 \mathrm{~h}$ and simultaneously treated with quercetin $(1-50 \mu \mathrm{M})$. Proinflammatory cytokine, TNF- $\alpha$ and anti-inflammatory cytokine, IL-13 gene expression was studied by qRTPCR after $24 \mathrm{~h}$ of stimulation, whereas protein secretion was determined in cell culture supernatants by ELISA after $96 \mathrm{~h}$ of stimulation. TNF- $\alpha$ and IL-13 protein secretion was quantitated using a commercially available ELISA kit obtained from Bio Source International (Camarillo, CA) as per manufacturer's instructions.

Statistics: Experiments were performed at least three times and the values obtained were averaged. Data are represented as Mean \pm SE. Comparisons between two groups were conducted using Student's paired t-test. Differences were considered significant at $\mathrm{p} \leq 0.05$, with two-tailed test. Data analysis was performed with the Statistical Program, Graphpad prism software (La Jolla, CA).

\section{RESULTS}

Quercetin inhibits HIV-1 LTR gene expression in PBMCs: In the present study, the anti-HIV activity of flavonoid, quercetin was evaluated using an in vitro infection model in PBMCs. Data showed in Fig. 1 shows the effect of quercetin on HIV-1 LTR gene suppression in PBMC infected with HIV-1. PBMC $\left(3 \times 10^{6}\right.$ cells $\left.\mathrm{mL}^{-1}\right)$ were cultured with and without quercetin at different concentrations for 7 days after the HIV-1 IIIB infection. Cells were harvested, RNA was extracted and reverse transcribed to obtain cDNA which was used further to quantitate LTR gene expression by qRT-PCR. Results obtained were transformed to obtain Transcript Accumulation Index (TAI) and plotted as \% LTR expression with quercetin treatment. Our data shows that quercetin significantly downregulated LTR gene expression in a dose dependent manner at concentrations of $5 \mu \mathrm{M}$ $(17 \%, \mathrm{p}=0.069), 10 \mu \mathrm{M}(40 \%, \mathrm{p}=0.014), 25 \mu \mathrm{M}$ $(72 \%, \mathrm{p}=0.0005)$ and $50 \mu \mathrm{M}(88 \%, \mathrm{p}=0.000006)$ compared to HIV infected untreated control cultures (100\%) (Fig. 1a).

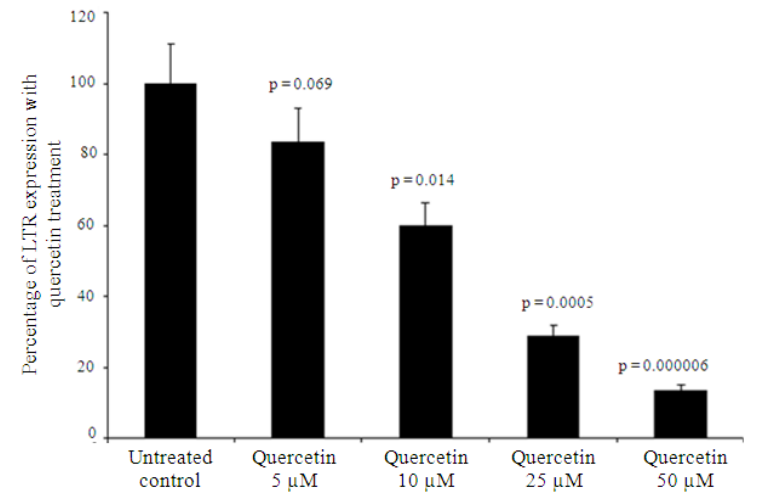

Fig. 1a: Effect of quercetin on LTR gene suppression in PBMC infected with HIV-1 IIIB

Note: Effect of quercetin on LTR gene suppression in PBMC infected with HIV-1. PBMC $\left(3 \times 10^{6}\right.$ cells $\left.\mathrm{mL}^{-1}\right)$ infected with HIV-1 IIIB were treated with quercetin $0-50 \mu \mathrm{M}$ for 7 days. Cells were harvested, RNA was extracted and reverse transcribed followed by quantitative real time PCR for LTR gene. Relative expression of mRNA species was calculated using the comparative $\mathrm{C}_{\mathrm{T}}$ method. The data represents the means $\pm \mathrm{SE}$ of 3 independent experiments. Statistical significance was calculated by students " $t$ " test

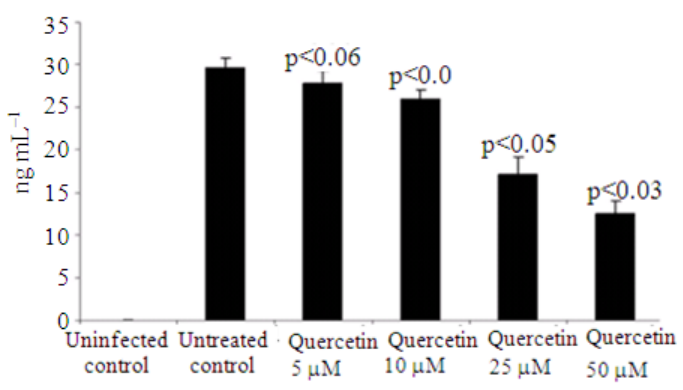

Fig. 1b: Effect of quercetin on p24 production in PBMC infected with HIV-1 IIIB

Note: Effect of quercetin on p24 production in PBMC infected with HIV-1. PBMC $\left(3 \times 10^{6}\right.$ cells $\left.\mathrm{mL}^{-1}\right)$ infected with HIV-1 IIIB were treated with quercetin $0-50 \mu \mathrm{M}$ for 7 days After incubation, supernatants were collected and analyzed for HIV-1 p24 antigen levels by ELISA. The data represents the means \pm SE of 3 independent experiments. Statistical significance was calculated by students " $t$ " test

Quercetin inhibits HIV-1 p24 antigen production in PBMC: Further we performed measurement of HIV-1 p24 protein levels from cell culture supernatants by ELISA. Data showed in Fig. 1b shows HIV-1 p24 antigen levels in culture supernatants of PBMC infected with HIV-1 and cultured with or without quercetin at 5$50 \mu \mathrm{m}$ concentrations. A dose dependent decrease in HIV-1 p24 protein production was observed upon treatment with quercetin at varying concentration $5 \mu \mathrm{M}$ $\left(28 \mathrm{ng} \mathrm{mL}^{-1}\right), 10 \mu \mathrm{M}\left(25.7 \mathrm{ng} \mathrm{mL}^{-1} ; \mathrm{p}<0.004\right), 25 \mu \mathrm{M}$ (16.9 $\left.\mathrm{ng} \mathrm{mL}{ }^{-1} ; \mathrm{p}<0.05\right)$ and $50 \mu \mathrm{M}\left(12.1 \mathrm{ng} \mathrm{mL}^{-1}\right.$; $\mathrm{p}<0.03)$ compared to HIV infected untreated control cultures $\left(29.8 \mathrm{ng} \mathrm{mL}^{-1}\right)$. 
Am. J. Infect. Dis., 5 (2): 135-141, 2009

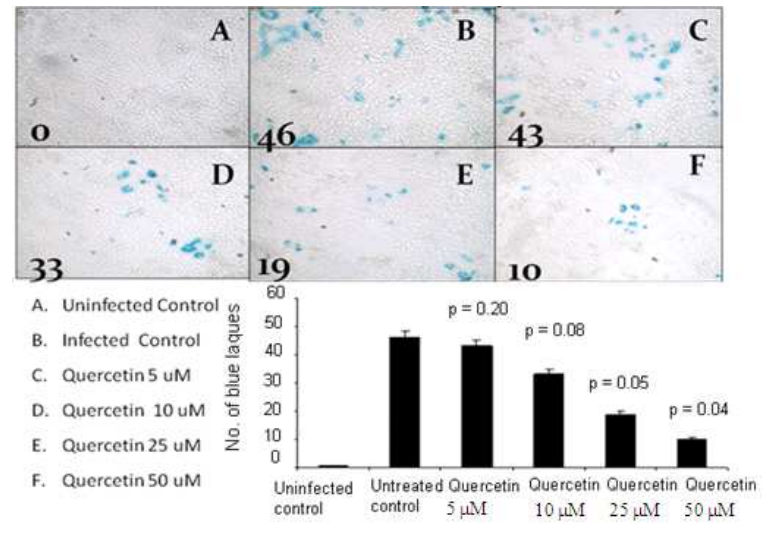

Fig. 2: Effect of quercetin on HIV-1 IIIB virus infectivity in PBMC by MAGI cell assay

Note: Effect of quercetin on MAGI cell assay. MAGI cells $\left(4 \times 10^{4}\right.$ cells well $\left.^{-1}\right)$ were treated with $100 \mu \mathrm{L}$ cell suspension of PBMCs that were infected with HIV-1 IIIB virus and subsequently treated with quercetin $(5-50 \mu \mathrm{M})$ and incubated for 3 days at $37^{\circ} \mathrm{C}, 5 \% \mathrm{CO}_{2}$. Cells were fixed and stained with 5-bromo-4-chloro-3-indolyl-D-galactopyranoside (X-Gal) and blue cells were counted as infected cells. The data represents the means \pm SE of 3 independent experiments. Statistical significance was calculated by students " $\mathrm{t}$ " test

Quercetin inhibits HIV-1 virus infectivity in PBMC by MAGI cell assay: We also measured HIV-1 infectivity using the MAGI assay that allows detection of HIV-1 after a single viral replication cycle in supernatant of quercetin treated infected PBMC cultures. Our results showed a decrease in number of HIV-1 infected cells as represented by the decreased number of blue cells with increasing concentrations of quercetin. Percentage of HIV-1 infected cells at 5, 10, 25 and $50 \mu \mathrm{M}$ concentrations of quercetin were $43 \%$ $(\mathrm{p}=0.2, \mathrm{NS}), 33 \%(\mathrm{p}=0.08, \mathrm{NS}), 19 \%(\mathrm{p}=0.05)$ and $10 \%(\mathrm{p}=0.04)$ respectively compared to the $46 \%$ in the HIV-1 infected untreated control (Fig. 2).

Differential modulation of pro-and antiinflammatory cytokine by quercetin in PBMC: Previously, we have reported that quercetin inhibits expression of pro-inflammatory cytokine TNF- $\alpha$ in normal PBMC via modulation of the NFKB system ${ }^{[19]}$. In the current study, we investigated whether quercetin exerts differential effect on expression of pro- and antiinflammatory cytokines in normal PBMC. PBMCs were stimulated with PMA and calcium ionophore and simultaneously treated with quercetin $(1-50 \mu \mathrm{M})$ for 24$96 \mathrm{~h}$. After $24 \mathrm{~h}$ incubation, cells were harvested to determine pro-inflammatory cytokine, TNF- $\alpha$ and antiinflammatory cytokine, IL-13 gene expression by qRTPCR. Result indicates that quercetin downregulated TNF- $\alpha$ gene expression by PBMCs in a dose dependent manner in the concentration range of $10-50 \mu \mathrm{M}$ (Fig. 3a).

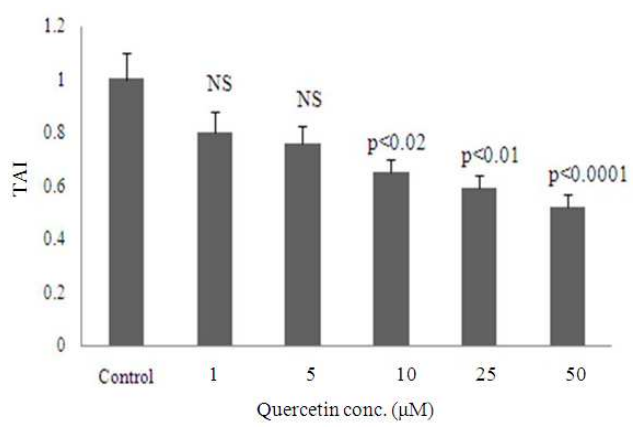

Fig. 3a: Effect of quercetin on pro-inflammatory cytokine, TNF- $\alpha$ gene expression

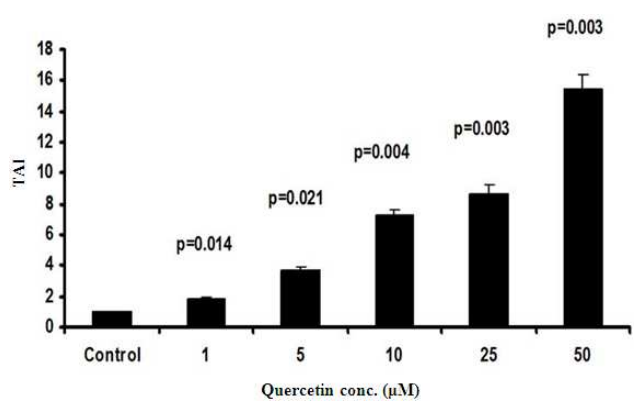

Fig. 3b: Effect of quercetin on anti-inflammatory cytokine IL-13 gene expression

Note: Effect of quercetin on stimulated TNF- $\alpha$ and IL-13 gene expression in PBMC. PBMCs $\left(3 \times 10^{6}\right.$ cells $\left.\mathrm{mL}^{-1}\right)$ were

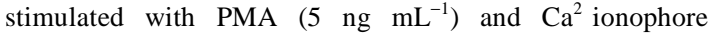
(50 $\mathrm{ng} \mathrm{mL}$ ) for $24 \mathrm{~h}$ and simultaneously treated with quercetin $(1-50 \mu \mathrm{M})$. Cells were harvested, RNA was extracted and reverse transcribed followed by qRT-PCR for TNF- $\alpha$ (Fig. 3a) and IL-13 (Fig. 3b) gene expression. Relative expression of mRNA species (TAI) was calculated using the comparative $\mathrm{C}_{\mathrm{T}}$ method. The data represents the means $\pm \mathrm{SE}$ of 3 independent experiments. Statistical significance was calculated by students " $\mathrm{t}$ " test

On the contrary, IL-13 gene expression was significantly upregulated in the quercetin $(1-50 \mu \mathrm{M})$ treated cultures compared to untreated cultures (Fig. 3b).

To substantiate gene expression results, we measured cytokine protein secretion from culture supernatants stimulated with PMA and treated with quercetin $(1-50 \mu \mathrm{M})$ for $96 \mathrm{~h}$. Data showed in Fig. 4a shows that quercetin at $5 \mu \mathrm{M}\left(200 \mathrm{pg} \mathrm{mL}^{-1}, \mathrm{p}=0.026\right)$ and $10 \mu \mathrm{M}\left(189 \mathrm{pg} \mathrm{mL}^{-1}, \mathrm{p}=0.016\right)$ significantly inhibited secretion of TNF- $\alpha$ cytokine, while $25 \mu \mathrm{M}$ and $50 \mu \mathrm{M}$ quercetin treatment resulted in complete inhibition of TNF- $\alpha$ secretion compared to untreated cultures. Interestingly, IL-13 protein secretion was significantly upregulated $(\mathrm{p}<0.001)$ in a dose dependent manner in the concentration range of $1-50 \mu \mathrm{M}$ of quercetin (Fig. 4b). 


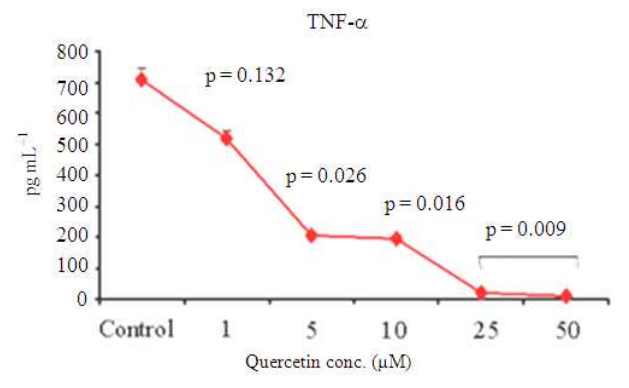

Fig. 4a: Quercetin downregulates $\mathrm{TNF}-\alpha$ protein secretion in PBMC

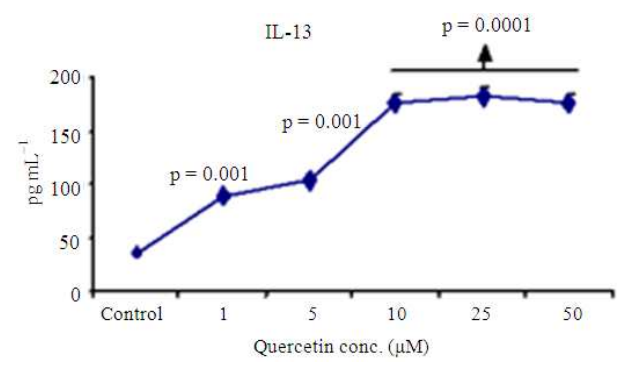

Fig. 4b: Quercetin upregulates IL-13 protein secretion in PBMC

Note: Effect of quercetin on TNF- $\alpha$ and IL-13 protein secretion in PBMC. PBMCs $\left(3 \times 10^{6}\right.$ cells $\left.\mathrm{mL}^{-1}\right)$ were stimulated with PMA ( $5 \mathrm{ng} \mathrm{mL}^{-1}$ ) and $\mathrm{Ca}^{2}$ ionophore $\left(50 \mathrm{ng} \mathrm{mL}^{-1}\right.$ ) for $96 \mathrm{~h}$ and simultaneously treated with quercetin $(1-50 \mu \mathrm{M})$. After incubation, culture supernatants were collected and analyzed by ELISA for TNF- $\alpha$ (Fig. 4a) and IL-13 (Fig. 4b) protein levels. The data represents the means \pm SE of 3 independent experiments. Statistical significance was calculated by students " $\mathrm{t}$ " test

\section{DISCUSSION}

Flavonoids represent a group of phytochemicals that are known to offer significant health benefits to humans. Flavonoids have been recognized to exert antibacterial and antiviral activity, anti-inflammatory, antiangiogenic and antiallergic effects, analgesic, hepatoprotective, cytostatic, apoptotic, estrogenic and antiestrogenic properties ${ }^{[3-14]}$. Quercetin is the most ubiquitous flavonoid in nature that exhibits a wide range of biological activities arising mainly from its antioxidant property and ability to modulate several enzymes or cell receptors. The current study shows that quercetin exerts significant anti-HIV activity by inhibiting HIV replication and reducing virus infectivity in PBMCs as measured by HIV-LTR gene expression, p24 antigen production and MAGI cell assay. Further, we also report that quercetin downregulates the expression of pro-inflammatory cytokine, TNF- $\alpha$ with a concomitant upregulation of anti-inflammatory cytokine, IL13. The differential modulations of pro-and anti-inflammatory cytokines play a major role in the infection and pathogenesis of HIV disease.

Previous studies from our laboratory demonstrate that quercetin differentially regulates gamma interferon (IFN- $\gamma$ ) and IL-4 expression in PBMCs ${ }^{[25]}$. Further, we have also shown that flavonoids from grape seed extracts downregulates the expression of HIV-1 entry co-receptors, CCR2b, CCR3 and CCR5 in normal PBMCs ${ }^{[26]}$, which suggests that flavonoids can interfere with the binding of the virus to the cell receptor and, thus can prevent HIV entry into the normal lymphocyte. In addition, the findings from this study support data demonstrating the ability of quercetin to modulate a variety of inflammatory cytokines and their role in HIV infection. HIV-1 infection and virus replication are regulated by a complex network of cytokines secreted by a variety of cells. TNF- $\alpha$ is one of the major proinflammatory cytokines that significantly upregulate HIV-1 production in Monocytes-Derived Macrophages (MDM) through the activation of NF- $\kappa \mathrm{B}$ signaling ${ }^{[27]}$. On the other hand, IL-13 exerts anti-inflammatory activity by inhibiting production of pro-inflammatory cytokines such as TNF- $\alpha$ and inhibits HIV-1 production $^{[28]}$. Previous studies have reported that IL-13 acts on macrophages before and after HIV-1 infection and blocks the completion of reverse transcription, inhibits virus production and reduces the infectivity of the progeny virions ${ }^{[29]}$. Further, IL-13 is also known to suppress TNF- $\alpha$ induced activation of NF- $\kappa \mathrm{B}$, Activation Protein-1 and apoptosis, which describes its immunosuppressive and anti-inflammatory effects ${ }^{[30]}$. Our results showing significant downregulation of TNF- $\alpha$ by quercetin could probably be attributed to increased levels of IL-13. These findings suggest that in addition to downregulation of HIV entry co-receptors by quercetin, differential modulation of pro-and antiinflammatory cytokines expression could be the potential mechanisms for the anti-HIV activity of quercetin.

\section{CONCLUSION}

Quercetin displays a diverse array of biological effects, which is mainly attributed to its antioxidant and anti-inflammatory properties. Elucidating the molecular mechanisms of quercetin-induced anti-HIV effects may help to develop novel flavonoid-based neutraceutical agents useful in the treatment of HIV infection. Furthermore, these studies may provide new 
information and impetus for developing a potential clinical trial of quercetin as an adjunct nutritional supplement, along with the existing antiviral therapeutic regimen, in the treatment of HIV infection.

\section{ACKNOWLEDGEMENT}

This study was supported in part by National Institute on drug RO1-DA012366, RO1-DA014218, RO1-DA015628 and RO1-DA021537.

\section{REFERENCES}

1. Hertog, M.G., P.C. Hollman, M.B. Katan and D. Kromhout, 1993. Intake of potentially anticarcinogenic flavanoids and their determinanants in adults in the Netherlands. Nutr. Cancer, 20: 21-29.

http://www.ncbi.nlm.nih.gov/pubmed/8415127

2. Manach, C., F. Regerat, O. Taxier, C. Demigne and C. Remesy, 1996. Bioavailability, metabolism and physiological impact of 4-oxo-flavonoids. Nutr. Res., 16: 517-544. DOI: 10.1016/02715317(96)00032-2

3. Kandaswami, C. and E. Middleton, 1994. Free radical scavenging and antioxidant activity of plant flavonoids. Adv. Exp. Med. Biol., 366: 351-376. http://www.ncbi.nlm.nih.gov/pubmed /7771265

4. Korkina, L.G. and I.B. Afanas'ev, 1997. Antioxidant and chelating properties of flavonoids. Adv. $\quad$ Pharmacol., 38: 151-163. http://www.ncbi.nlm.nih.gov/pubmed/8895808

5. Li, B.Q., T. Fu, Y. Dongyan, J.A. Mikovits, F.W. Ruscetti and J.M. Wang, 2000. Flavonoid baicalin inhibits HIV-1 infection at the level of viral entry. Biochem. Biophys. Res. Commun., 276: 534-538. DOI: 10.1006/bbrc.2000.3485

6. Middleton, E.J., C. Kandaswami and T.C. Theoharides, 2000. The effects of plant flavonoids on mammalian cells: Implications for inflammation, heart disease and cancer. Pharmacol. Rev., 52: 673-751. www.ncbi.nlm.nih.gov/pubmed/11121513

7. Busse, W.W., D.E. Kopp and E. Middleton Jr., 1984. Flavonoid modulation of human neutrophil function. J. Allergy Clin. Immunol., 73: 801-809. http://www.ncbi.nlm.nih.gov/pubmed/6327791

8. Camuesco, D., M. Comalada, M.E. Rodriguez-Cabeza, A. Nieto, M.D. Lorente, A. Concha, A. Zarzuelo and J. Galvez, 2004. The intestinal antiinflammatory effect of quercetin is associated with an inhibition in iNOS expression. Br. J. Pharmacol., 143: 908-918. DOI: 10.1038/sj.bjp.0705941
9. Comalada, M., D. Camuesco, S. Sierra, I. Ballester, J. Xaus, J. Galvez and Zarzuelo, 2005. In vivo quercitrin anti-inflammatory effect involves release of quercetin, which inhibits inflammation through down-regulation of the NF-kappaB pathway. Eur. J. Immunol., 35: 584-592. http://www.ncbi.nlm.nih.gov/pubmed/15668926

10. Kawada, N., S. Seki, M. Inoue and T. Kuroki, 1998. Effect of antioxidants, resveratrol, quercetin and $\mathrm{N}$ - acetylcysteine, on the functions of cultured rat hepatic stellate cells and Kupffer cells. Hepatology, 27: 1265-1274. http://www.ncbi.nlm.nih.gov/pubmed/9581680

11. Middleton, E. Jr., 1998. Effect of plant flavonoids on immune and inflammatory cell function. Adv. Exp. Med. Biol., 439: 175-182. http://www.ncbi.nlm.nih.gov/pubmed/9781303

12. Nair, H.K., K.V. Rao, R. Aalinkeel, S. Mahajan, R. Chawda and S.A. Schwartz, 2004. Inhibition of prostate cancer cell colony formation by the flavonoid quercetin correlates with modulation of specific regulatory genes. Clin. Diagn. Lab. Immunol., 11: 63-69. DOI: 10.1128/CDLI.11.1.6369.2004

13. Nair, M.P., C. Kandaswami, S. Mahajan, K.C. Chadha, and R. Chawda et al., 2002. The flavonoid, quercetin, differentially regulates Th-1 (IFNgamma) and Th-2 (IL4) cytokine gene expression by normal peripheral blood mononuclear cells. Biochem. Biophys. Acta, 1593: 29-36. http://www.ncbi.nlm.nih.gov/pubmed/12431781

14. Wang, J. and G. Mazza, 2002. Effects of anthocyanins and other phenolic compounds on the production of tumor necrosis factor alpha in $\begin{array}{lll}\text { LPS/IFNgamma-activated } & \text { RAW } & 264.7\end{array}$ macrophages. J. Agric. Food Chem., 50: 4183-4189. DOI: $10.1021 /$ jf011613d

15. Sato, M., T. Miyazaki, F. Kambe, K. Maeda and H. Seo, 1997. Quercetin, a bioflavonoid inhibits the induction of interleukin 8 and monocytes chemoattractant protein-1 expression by tumor necrosis factor- $\alpha$ in cultured human synovial cells. J. Rheum., 24: 1680-1684. http://www.ncbi.nlm.nih.gov/pubmed/9292787

16. Cho, S.Y., S.J. Park, M.J. Kwon, T.S. Jeong and W.Y. Choi et al., 2003. Quercetin suppresses proinflammatory cytokines production through MAP kinases and NF- $\kappa$ B pathway in lipopolysacchride-stimulated macrophage. Mol. Cell. Biochem., 243: 153-160. DOI: 10.1023/A: 1021624520740 
17. Wadsworth, T.L. and R.K. Dennis, 1999. Effects of the wine polyphenolics quercetin and resveratrol on pro-inflammatory cytokine expression in Raw 264.7 macrophages. Biochem. Pharmacol., 57: 941-949. DOI: 10.1016/S0006-2952(99)00002-7

18. Min, Y.D., C.H. Choi, H. Bark, H.Y. Son and H.H. Park et al., 2007. Quercetin inhibits expression of inflammatory cytokines through attenuation of $\mathrm{NF \kappa B}$ and p38 MAPK in HMC-1 human mast cell line. Inflamm. Res., 5: 210-215. DOI: $10.1007 / \mathrm{s} 00011-007-6172-9$

19. Nair, M.P., S. Mahajan, J.L. Reynolds, R. Alinkeel, H. Nair, S.A. Schwartz and C. Kandaswami, 2006. The flavonoid quercetin inhibits proinflammatory cytokine (tumor necrosis factor alpha) gene expression in normal peripheral blood mononuclear cells via modulation of the $\mathrm{NF}-\kappa \mathrm{B}$ system. Clin. Vac. Immuno., 13: 319-328. DOI: 10.1128/CVI.13.3.319-328.2006

20. Nair, M.P.N., C. Kandaswami, A. Sweet and S.A. Schwartz, 1998. The flavonoid, Quercetin, downregulates HIV-1 entry coreceptor, CCR5, gene expression by normal Peripheral Blood Mononuclear Cells (PBMC).

http://www.oxyclubcalifornia.org/pastoccs/1998/po ster06.html

21. Hubbard, G.P., S. Wolffram, J.A. Lovegrove and J.M. Gibbins, 2004. Ingestion of quercetin inhibits platelet aggregation and essential components of the collagen-stimulated platelet activation pathway in humans. J. Thromb. Haemost., 2: 2138-2145. http://www.ncbi.nlm.nih.gov/pubmed/15613018

22. Shively, L., L. Chang, J.M. LeBon, Q. Liu, A.D. Riggs and J. Singer-Sam, 2003. Real-time PCR assay for quantitative mismatch detection. Biotechniques, 34: 498-502. http://www.ncbi.nlm.nih.gov/pubmed/12669699

23. Mahajan, S., S. Schwartz and M.P. Nair, 2003. Immunological assays for chemokine detection in in vitro culture of CNS cells. Biol. Proc. Online, 5: 90-102. DOI: 10.1251/BPO50

24. Chackerian, B., E.M. Long, P.A. Luciw, J. Overbaugh, 1997. Human immunodeficiency virus type 1 coreceptors participate in post-entry stages in the virus replication cycle and function in simian immunodeficiency virus infection. J. Virol., 71: 3932-3939.

http://www.ncbi.nlm.nih.gov/pubmed /9094670
25. Nair, M.P.N., C. Kandaswami, S. Mahajan, C. Kailash and R. Chawda et al., 2002. The flavonoid, quercetin, differentially regulates $\mathrm{Th}-1$ (IFNg) and Th-2 (IL4) cytokine gene expression by normal peripheral blood mononuclear cells. Biochim. Biophys. Acta, 1593: 29-36. DOI: 10.1016/S01674889(02)00328-2

26. Nair, M.P., C. Kandaswami, S. Mahajan, H.N. Nair, R. Chawda, T. Shanahan and S.A. Schwartz, 2002. Grape seed extract proanthocyanidins downregulate HIV-1 entry coreceptors, CCR2b, CCR3 and CCR5 gene expression by normal peripheral blood mononuclear cells. Biol. Res., 35: 421-431. http://www.ncbi.nlm.nih.gov/pubmed/12462994

27. Herbein, G. and S. Gordon, 1997. 55- and 75kilodalton tumor necrosis factor receptors mediate distinct actions in regard to human immunodeficiency virus type 1 replication in primary human macrophages. J. Virol., 71: 4150-4156. http://www.ncbi.nlm.nih.gov/pubmed/9094699

28. Montaner, L.J., A.G. Doyle, M. Collin, G. Herbein, P. Illei, W. James, A. Minty, D. Caput, P. Ferrara and S. Gordon, 1993. Interleukin 13 inhibits human immunodeficiency virus type 1 production in primary blood-derived human macrophages in vitro. J. Exp. Med., 178: 743-747. http://www.ncbi.nlm.nih.gov/pubmed/8101865

29. Montaner L.J., R.T .Bailer and S. Gordon, 1997. IL-13 acts on macrophage to block the completion of reverse transcription, inhibit virus production and reduce virus infectivity. J. Leukoc. Biol., 62: 126-132.

http://www.ncbi.nlm.nih.gov/pubmed/9226003

30. Manna, S.K. and B.B. Aggrawal, 1998. IL-13 suppresses TNF-induced activation of nuclear factor- $\kappa \mathrm{B}$, activation protein-1 and apoptosis. J. Immunol., 161: 2863-2872.

http://www.ncbi.nlm.nih.gov/pubmed/9743347 